\title{
Sistema lean para otimização de recursos em uma indústria moveleira: estudo de caso com foco nas ferramentas da produção enxuta
}

Patrick Rusivel Brito de Lima patricklima_eng@yahoo.com.br Universidade Federal do Pará (UFPA) Abaetetuba, Pará, Brasil

Vitor William Batista Martins patricklima_eng@yahoo.com.br Universidade Estadual do Pará (UEPA), Belém, Pará, Brasil

\section{RESUMO}

Com o mercado cada vez mais exigente, as indústrias devem se adequar para atender seus clientes com qualidade e rapidez. Para se manter competitiva no mercado, seus conceitos e filosofias devem ser renovados. Levando em consideração a mudança dos cenários das organizações em geral, o desafio é aliado à agilidade tecnológica de seus concorrentes, para isso, deve-se ter um cenário adaptativo para diversas situações, pois desenvolver sistemas eficientes, melhorar a produtividade, definir padrões aumentar o nível de serviço são alguns dos diferenciais para se manter no mercado. O objetivo desse artigo foi demonstrar os benefícios do Pensamento Enxuto aplicado em uma Indústria Moveleira. A metodologia consistiu em coletar dados de forma quantitativa, com isso verificar o uso das ferramentas e o que as mesmas podem agregar nos processos produtivos. Isso consiste na eliminação de desperdícios, redução dos custos de produção e padronização das operações nos processos. Algumas das melhorias obtidas com o estudo são: todas paradas para estoque foram eliminadas fazendo o processo seguir um fluxo contínuo, o número de funcionários por células em uma delas passou de 4 para 1, a eliminação de operações que não agregam valor ao produto como: colocar cavilha e furar, redução do custo de produção em $29 \%$ e aumento da quantidade produzida por hora em $18 \%$.

PALAVRAS-CHAVE: Pensamento Enxuto. Células de Manufatura. Mapeamento de Fluxo de Valor. 


\section{INTRODUÇÃO}

Para sobreviver, as empresas atualmente devem se manter competitivas no mercado, para isso precisam de sistemas organizacionais eficientes. Com base nisso, escolheu-se o Lean Manufacturing (ou Manufatura Enxuta), cujo foco é a absoluta eliminação ou redução dos desperdícios.

As empresas atuais apresentam processos de produção bastante complexos, trabalhando com uma variedade de produto muito maior. Com isso se torna difícil para organização identificar gargalos dentro do processo. As empresas apresentam desperdícios como: Estoque, ociosidade de máquina e mão de obra, movimentação desnecessária, retrabalhos e má utilização de recursos financeiros para tecnologias desnecessárias (RAGADALLI, 2010).

O foco desta pesquisa foi uma indústria do ramo de móveis e utilidades situada em Belém, Estado do Pará, cuja produção e embalagem apresentam longos Lead Times. Por meio de análises na empresa e com a implantação de mapa de fluxo de valor (MFV), células de manufatura (CM) e balanceamento de fluxo e carga (BFC), foi possível o conhecer seu sistema, sua filosofia e quantificar seus dados.

A demanda globalizada por qualidade e preços baixos vem causando mudanças nos cenários das empresas. As organizações em geral têm o desafio, que é sobreviver a constante competitividade aliada à agilidade tecnológica de seus concorrentes, para isso, deve-se ter um cenário adaptativo para diversas situações, pois desenvolver sistemas eficientes, melhorar a produtividade, definir padrões para aumentar o nível de serviço são alguns dos diferenciais.

Com o mercado mais exigente, as indústrias devem se adequar para atender seus clientes com qualidade e rapidez. Contudo para se manterem nesse mercado de maneira competitiva, seus conceitos e filosofias devem ser renovados. Para se tornar uma empresa enxuta, deve-se controlar todas as etapas da cadeia de processo desde a matéria prima até a chegada do produto final aos clientes.

Segundo Taiichi Ohno explicou em 1988:

O que estamos fazendo é observar a linha de tempo desde o momento em que o cliente nos faz um pedido até o ponto em que recebemos o pagamento". E estamos reduzindo essa linha de tempo, removendo as perdas que não agregam valor. (LIKER, 2005, p.)

A produção enxuta baseia-se essencialmente em cultivar habilidades de liderança que deem aos clientes o que desejam, quando desejam, com o máximo de qualidade e a um custo competitivo. Para atender a essas características, exige que o fabricante reduza custos, melhore sua produtividade, seus níveis de serviço, aperfeiçoe e desenvolva seus processos de maneira enxuta.

O sistema de produção enxuta surge da necessidade das empresas japonesas, em especial a Toyota Motor Company, desenvolvendo métodos diferenciados para a fabricação de veículos em relação às outras indústrias que é o caso do sistema de produção em massa da Ford Company e General Motors, pela vasta experiência dessas grandes montadoras em produzir em massa, para a Toyota competir com base nos mesmos conceitos não seria viável. Isso resultou em um novo modelo de sistema de produção, conhecido como Sistema Toyota de Produção (STP) ou Sistema de produção Enxuto (Lean Manufacturing/Lean Production). 
De acordo o surgimento de novas empresas, a competitividade por preços tenderá estar equiparada entre as mesmas. A partir desta "guerra" entre preços, a variável a ser focada pelas empresas será o custo de produção (UP), tendo uma busca por um processo enxuto com a menor presença de desperdícios. Neste contexto as ferramentas de mapeamento de fluxo de valor (MFV), célula de manufatura (CM) e balanceamento de fluxo e carga (BFC), são apresentadas como um meio a ser aplicado, pois dentro de sua mentalidade busca a exposição e eliminação do desperdício, a redução do lead time e fluxo produtivo otimizado.

De acordo com Rother e Shook (1999) o mapeamento de fluxo de valor analisa o processo e identifica desperdício, entraves ao fluxo e oportunidades de melhoria. Demonstrando a relação entre o fluxo de informação e o fluxo de material de forma a otimizar do processo, através da análise do processo geral da empresa, sincronizando os dois tipos de fluxos.

Segundo Wermmerlov e Johnson (1997), que conceituam a célula de manufatura como uma forma de organização do trabalho. Deste modo, a célula de manufatura não está limitada ao planejamento do arranjo físico, incluindo todo o planejamento do sistema sociológico e técnico envolvido em seu funcionamento.

Assim, a célula de manufatura é composta por fatores técnicos, como, por exemplo, o agrupamento de processos e produtos, bem como em fatores sociais, como, por exemplo, os mecanismos de supervisão e grau de autonomia dos operadores (HYER et al., 1999).

Hyer e Brown (1999) partiram do sistema técnico para desenvolver uma nova abordagem, afirmando que as células de manufatura devem possuir um fluxo de trabalho onde processos e operadores estejam intimamente conectados em relação aos elementos tempo, espaço e informação.

\section{REFERENCIAL TEÓRICO}

A Produção Enxuta surgiu no Japão, no período pós Segunda Guerra Mundial, cuja proeminente aplicação se deu na Toyota Motor Company. O então engenheiro-chefe da Toyota, TAIICHI OHNO, em visita às fábricas da Ford nos Estados Unidos, percebeu que os americanos estavam adiantados em relação à eficiência produtiva comparada ao Japão.

Devastado pela guerra, e sem recursos para realizar altos investimentos necessários para a implantação da produção em massa, que caracterizava o sistema implantado por Henry Ford e da General Motors. Os países também tinham outras séries de problemas e desafios a serem contornados como: mercado interno limitado e demandando vasta variedade de produtos, existência de vários fabricantes de veículos do mundo interessados em ingressar no Japão, dentre outros.

Aliado às restrições acima, ainda havia o fato de que a mão-de-obra nativa não estava disposta a ser tratada como peça intercambiável do sistema produtivo, havia a dificuldade de importação de peças e matérias primas e a concorrência estrangeira dentro do Japão (ZACHER, 2004).

Com isso OHNO concluiu que algumas adaptações eram necessárias para que as empresas japonesas pudessem crescer em um mercado que exigia menor quantidade e maior variedade (WOMACK et al., 1992). 
Tendo como vista tentar responder a escassez de recursos e a intensa competição da indústria automobilística, A Toyota Motor Company, representa uma alternativa à forma de produção em massa (OHNO, 1997).

Segundo Ohno (1997), devido à escassez de matérias primas e recursos, A Toyota começou a acompanhar a linha do tempo desde o momento em que o pedido do cliente é realizado até o momento em que o pagamento é efetuado, estudar essa linha do tempo e reduzi-la, de modo a remover as perdas que não agregam valor.

Já que a Toyota não poderia se dar ao luxo de produzir gastando muito devido a crise, surgiu à necessidade de se criar um novo modelo gerencial, para se tornar mundialmente competitiva o Sistema Toyota de Produção (STP) ou Manufatura Enxuta (Lean Manufacturing), foi estruturado por OHNO.

Os objetivos fundamentais deste novo sistema caracterizaram-se por fabricar produtos com maior variedade, com processos flexíveis e de qualidade, ampliando sua capacidade de produzir e competir no cenário internacional.

Os conceitos de Manufatura Enxuta se disseminaram pelo mundo e várias são suas definições uma delas é apresentada assim: "A eliminação de desperdícios e elementos desnecessários a fim de reduzir custos; a ideia básica é produzir apenas o necessário, no momento necessário e na quantidade requerida (OHNO, 1997)".

A nova filosofia se destacou no mundo inteiro apresentando ótimos índices de produtividade, qualidade e desenvolvimento de produtos. Assim, ao longo da última década, cada vez mais empresas buscam a utilização das práticas do sistema Toyota em sua produção (STEFANELLI, 2007).

\section{OS PRINCÍPIOS DO PENSAMENTO ENXUTO (LEAN THINKING)}

O Lean Thinking criado pelo sistema Toyota de produção tem como base os cinco princípios são definidos como fundamentais na eliminação das perdas, resumindo todo o pensamento enxuto.

Segundo Womack, Jones e Roos (1992), a produção enxuta se apoia em cinco princípios básicos, os quais têm por objetivo ajudar as empresas a serem mais flexíveis no atendimento ao cliente.

Esses princípios são ensinamentos que orientam as empresas que queiram adotar esta filosofia, mostrando o que deve ser realizado para alcançar seus objetivos. Fundamentos que são resumidos de acordo com o Lean Institute Brasil (LIB) como:

-Valor: O ponto de partida para a Mentalidade Enxuta consiste em definir o que é Valor. Diferente do que muitos pensam, não é a empresa, e sim o cliente quem define o que é valor. Para ele, a necessidade gera o valor, e cabe às empresas determinarem qual é essa necessidade, procurar satisfazê-la e cobrar por isso um preço específico, a fim de manter a empresa no negócio e aumentar seus lucros por meio da melhoria contínua dos processos, da redução de custos e da melhoria da qualidade;

-Fluxo de valor: O próximo passo consiste em identificar o Fluxo de Valor. Significa dissecar a cadeia produtiva e separar os processos em três tipos: aqueles que efetivamente geram valor; aqueles que não geram valor, mas são importantes 
para a manutenção dos processos e da qualidade; e, por fim, aqueles que não agregam valor, devendo ser eliminados imediatamente. Apesar de continuamente olharem para sua cadeia produtiva, as empresas continuam a focalizar em reduções de custos não acompanhadas pelo exame da geração de valor. Elas olham apenas para números e indicadores no curto prazo, ignorando os processos reais de fornecedores e revendedores. As empresas devem olhar para todo o processo, desde a criação do produto até a venda final (aliás, inclusive, até o pósvenda);

-Fluxo contínuo: A seguir, deve-se dar "fluidez" para os processos e atividades que restaram. Isso exige uma mudança na mentalidade das pessoas. Elas devem deixar de lado a ideia que têm de produção por departamentos como a melhor alternativa. Constituir Fluxo Contínuo com as etapas restantes é uma tarefa difícil do processo. É, também, a mais estimulante. O efeito imediato da criação de fluxos contínuos pode ser sentido na redução dos tempos de concepção de produtos, de processamento de pedidos e em estoques. Ter a capacidade de desenvolver, produzir e distribuir rapidamente dá ao produto uma "atualidade": a empresa pode atender à necessidade dos clientes quase que instantaneamente;

-Produção Puxada: Permite inverter o fluxo produtivo: as empresas não mais empurram os produtos para o consumidor (desovando estoques) através de descontos e promoções. O consumidor passa a Puxar o Fluxo de Valor, reduzindo a necessidade de estoques e valorizando o produto. Sempre que não se consegue estabelecer o fluxo contínuo, conectam-se os processos através de sistemas puxados;

-Perfeição: A Perfeição, quinto e último passo para a Mentalidade Enxuta, deve ser o objetivo constante de todos envolvidos nos fluxos de valor. A busca pelo aperfeiçoamento contínuo em direção a um estado ideal deve nortear todos os esforços da empresa em processos transparentes, em que todos os membros da cadeia (montadores, fabricantes de diversos níveis, distribuidores e revendedores) tenham conhecimento profundo do processo como um todo, podendo dialogar e buscar continuamente melhores formas de se criar valor.

\section{AS SETE PERDAS}

Segundo OHNO (1997), no sistema de Produção Enxuta tudo o que não agrega valor ao produto, visto sob os olhos do cliente, é desperdício. Todo desperdício apenas adiciona custo e tempo. Todo desperdício é o sintoma e não a causa do problema.

Para Womack, Jones e Roos (1992), Shingo (1996) e Ohno (1997), desperdício é toda atividade que adiciona custo, mas não agrega valor.

Segundo Ghinato (2000), na linguagem da engenharia industrial consagrada pela Toyota, perda são atividades desnecessárias que geram custos, não agregam valor e que deve ser eliminada.

Como já enfatizado o sistema Toyota visa essencialmente detectar e eliminar todas as perdas do sistema de produção, ou mesmo é o princípio do não custo que se baseia na eliminação da tradicional equação: custo + lucro = preço; substituindoa por preço - custo $=$ lucro. 
Seguindo a lógica tradicional os custos de produção mais o lucro pretendido era o que determinava o preço, assim repassando aos clientes todos os saldos negativos da negociação com o passar do tempo e com o aumento da competitividade de mercado passou-se a ter mais exigentes, assim o mercado passou a determinar preços, exigindo dos investidores novas posturas administrativas, onde o principal foco de mudança foi justamente na redução de custos.

Na Toyota essa redução de custo passa por uma minuciosa análise da cadeia de valor sendo a produção avaliada desde o momento da matéria prima até o produto acabado sendo que o sistema de produção avalia ainda, o setor operacional com o intuito de detectar e eliminar trabalhos que são executados durante a produção que não acrescentam valor ao produto final.

Aprender a enxergar os desperdícios a sua volta, é a chave para começar a sua jornada de transformação da sua organização em uma Lean Enterprise. Womack, Jones e Ross (1992) classificam os desperdícios em sete tipos, e serão descritos adiante.

Ainda na visão de OHNO (1997) a Produção Enxuta é o resultado da eliminação de sete tipos clássicos de desperdícios, também denominado de perdas, existentes dentro de uma empresa. Assim, atacando estes três pontos, pessoas, qualidade e quantidade, consegue-se minimizar, senão eliminar, os tipos de perdas no processo.

Segundo Shingo (1996) classifica as perdas em sete tipos: superprodução, transporte, processamento, fabricação de produtos defeituosos, movimento, espera e estoque. As sete perdas são listadas abaixo:

-Perdas por superprodução: referem-se à produção de itens acima do necessário ou antecipadamente;

-Perdas por transporte: referem-se basicamente às atividades de movimentação de materiais, as quais usualmente não adicionam valor ao produto;

-Perdas no processamento: propriamente dito correspondem às atividades de transformação desnecessárias para que o produto adquira suas características básicas de qualidade;

-Perdas por fabricação de produtos defeituosos: como o nome indica, originam-se na confecção de itens fora das especificações de qualidade;

-Perdas no movimento: relacionam-se à movimentação inútil na consecução das atividades, ou seja, à ineficiência da operação propriamente dita;

-Perdas por espera: são formadas pela capacidade ociosa, quer dizer, por trabalhadores e instalações parados, o que gera custos;

-Existência de estoques: gera as perdas por estoque, as quais são os custos financeiros para a manutenção dos estoques, custos devidos à obsolescência dos itens estocados e, principalmente, custos de oportunidade pela perda de mercado futuro para a concorrência com menor "lead time".

\section{PILARES DE SUSTENTAÇÃO}


O diagrama conhecido como a casa do Sistema Toyota de Produção é a representação de um sistema baseado em uma estrutura, não apenas um conjunto de técnicas (Liker, 2005). A figura 1 ilustra a casa STP na empresa onde esse trabalho foi desenvolvido.

Figura 1 - A casa STP da indústria moveleira

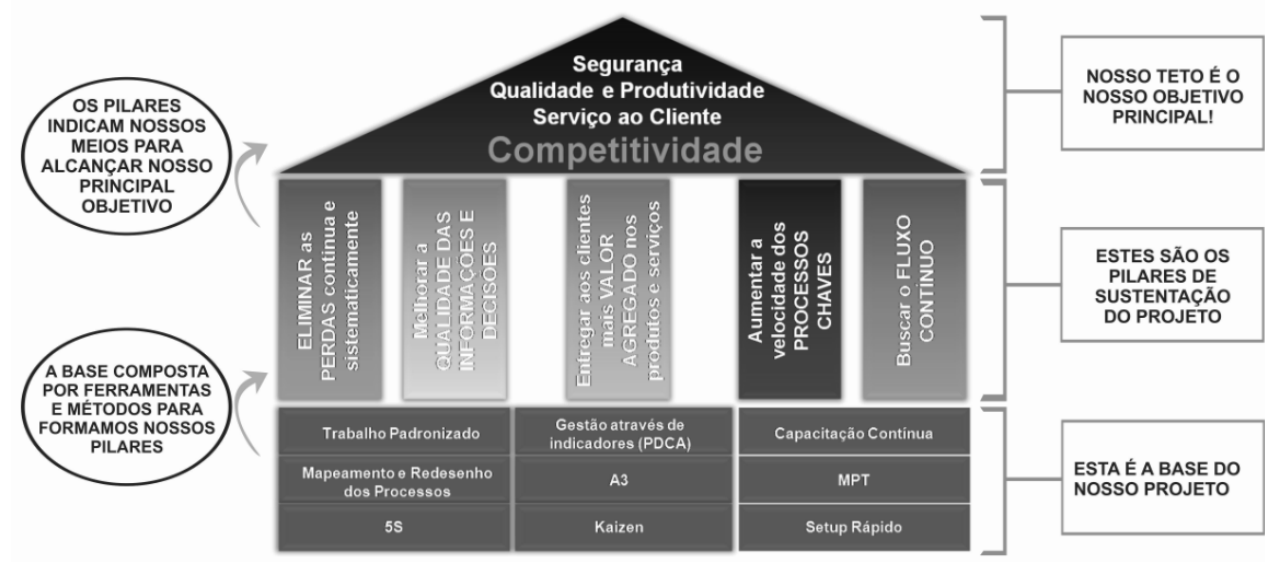

Fonte: Departamento de divulgação da empresa estudada (2014)

\section{MAPEAMENTO DE FLUXO DE VALOR}

Mapeamento de Fluxo de Valor é uma das ferramentas essenciais da Produção Enxuta, proposta por ROTHER e SHOOK (1998), que se basearam em uma técnica de modelagem proveniente da metodologia Análise da Linha de Valor.

O MFV Consiste no processo de identificação de todas as atividades específicas que ocorrem ao longo do fluxo de valor referente ao produto. Entendese por fluxo de valor o conjunto de todas as atividades que ocorrem desde a colocação do pedido até a entrega ao consumidor final.

A observação e compreensão do estado atual do produto na empresa e o desenho de um mapa dos processos tornará sua base para o Lean Manufacturing, ou seja, é uma representação visual de cada processo no fluxo do material e informação real que se reformulam um conjunto de questões chaves para se desenhar um mapa do estado futuro de como a produção deveria fluir.

ROTHER e SHOOK (1998) consideram o Mapeamento do Fluxo de Valor uma ferramenta essencial, pois auxilia na visualização do fluxo, mais do que simplesmente os processos individuais e ajuda na identificação dos desperdícios.

O mapeamento ajuda a identificar as fontes do desperdício, fornece uma linguagem comum para tratar dos processos de manufatura, torna as decisões sobre o fluxo visíveis, de modo que você possa discuti-las, engloba conceitos e técnicas enxutas, que ajuda a evitar a implementação de algumas técnicas isoladamente, forma a base para um plano de implementação e mostra a relação entre o fluxo de informação e o fluxo de material. A meta que se pretende alcançar pela Análise do Fluxo de Valor é a obtenção de um fluxo contínuo, orientado.

$\mathrm{O}$ grande diferencial do MFV é reduzir significativamente e de forma simples a complexidade do sistema produtivo e ainda oferecer um conjunto de diretrizes 
para a análise de possíveis melhorias. Nesse sentido, a técnica de Mapeamento do Fluxo de Valor auxilia no desenvolvimento conceitual da "situação futura" do sistema de produção enxuta pelas necessidades dos clientes, desde a matéria prima até o produto final.

\section{JUST IN TIME}

O Just in Time (JIT) é um sistema de programação para puxar o fluxo de produção e um sistema de controle de estoques. Isso significa que cada processo deve ser suprido com os itens certos, no momento certo, na quantidade certa e no local certo.

O objetivo do JIT é identificar, localizar e eliminar os desperdícios relacionados a atividades que não agreguem valor, reduzir estoques, garantindo um fluxo contínuo de produção.

O sistema consiste em fabricar somente o necessário, de preferência que se venda primeiramente, depois fabricar e posteriormente entregar. O JIT não se adapta facilmente a uma produção diversificada, pois em geral isto requereria extrema flexibilidade do sistema produtivo, em dimensões difíceis de serem obtidas neste sistema. Entretanto, este sistema tende a reduzir os custos operacionais, já que diminui a necessidade da mobilização e manutenção de espaço físico, principalmente na estocagem de matéria-prima ou de mercadoria a ser vendida.

\section{PADRONIZAÇÃO}

Uma ferramenta básica para a melhoria contínua, simples e fundamental para ser utilizada juntamente com o Lean é a Padronização.

É uma técnica que visa reduzir a variabilidade dos processos de trabalho, sem prejudicar sua flexibilidade. Isso significa que os produtos devem atender as expectativas dos clientes de forma regular e ao menor custo possível. Padronizar não significa perder flexibilidade para atender expectativas dos clientes nem sujeitar os trabalhadores a rotinas monótonas e normas rígidas.

A padronização é a principal técnica gerencial para a melhoria do desempenho de processos, que envolve as pessoas responsáveis pela execução do processo, visando aprender sobre o processo, atender as expectativas do cliente, aumentar a produtividade, eliminar desperdícios e melhorar a satisfação dos trabalhadores.

O Trabalho Padronizado é uma das formas mais eficiente de fazer um trabalho que maximiza a segurança, qualidade, custo, agenda e satisfação do consumidor, definindo e redefinindo o trabalho real e não a teoria.

\section{ESTUDO DE TEMPOS}

Segundo Peinado \& Graeml (2007), o estudo de tempos é uma maneira que nos permite mensurar o trabalho por meio de métodos quantitativos, possibilitando o cálculo do tempo padrão. Este método, de acordo com Starren 
(2000), é muitas vezes considerado o padrão-ouro para as medições de sistemas, de tarefas e duração.

Ao cronometrarmos os tempos despendidos para realização de uma tarefa, fica evidente a necessidade de observação da ação humana, que poderá ocasionar certa variabilidade no processo. Nesta situação, é fundamental que se considere eficiência dos funcionários envolvidos. A eficiência avalia a velocidade do operador em relação a um padrão mundial sem, no entanto, determinar se um trabalhador é mais competente do que outro (BARNES, 1977).

A literatura destaca alguns modos de realizar a escolha do funcionário a ser cronometrado. Peinado e Graeml (2007), e Martins e Laugeni (2006) mostram a possibilidade de a avaliação ser realizada por um observador experiente baseado no julgamento da velocidade dos funcionários. Os teóricos, Slack, Chambers e Johnston (2009) apontam que esta pode ser feita relativamente ao conceito do próprio observador a respeito da velocidade correspondente ao desempenho padrão, podendo este levar em consideração, separadamente ou em combinação, um ou mais fatores. É evidente, então o alto grau de subjetividade nesta abordagem.

Além dessas controvérsias há testes sistemáticos, entre eles está o desenvolvido por Barnes (1977), possibilitando assim, avaliar a velocidade do operador. Neste processo são distribuídas 52 (cinquenta e duas) cartas em um gabarito de fórmica, seguindo a distribuição, no mesmo sentido, por 05 (cinco) vezes. As distribuições são cronometradas, de posse dos resultados é realizado o cálculo para obtenção da média de tempo de cada operador (as duas primeiras medidas são descartadas), no intuito que seja determinado o operador padrão para poder ser realizada as cronometragens para o estudo (MARTINS \& LAUGENI, 2006). O tempo ideal para a distribuição é de 30 segundos, podendo ter uma variação entre 27 e 33 segundos ( $90 \%$ e $110 \%$ ), sendo a eficiência do trabalhador a razão entre o tempo obtido e o tempo ideal.

Definido o funcionário-padrão, deve-se determinar o número $\mathrm{N}$ de cronometragens que devem ser aferidas de forma a dar validade para os tempos encontrados. De acordo com Wirth et. al. (1977) um estudo de tempos pode ser realizado através da observação contínua ou amostragem do trabalho. Moreira (2009) mostra-nos o procedimento para obter o número de medidas $\mathrm{N}$ que é dado por:

$$
N=\left(\frac{100 \cdot z \cdot s}{a \cdot x}\right)^{2}
$$

Onde:

z = número de desvios padrão da normal padronizada, correspondente ao grau de confiança desejado;

$\mathrm{s}=$ desvio padrão da amostra de medidas;

a = precisão final desejada, em porcentagem;

$\mathrm{x}=$ média da amostra de medidas.

Esta expressão deve ser trabalhada com base em cronometragens preliminares, geralmente adotam-se valores para o grau de confiança $\mathrm{C}$ que variem 
entre $90 \%$ e $95 \%$, utilizamos a precisão no intervalo de $5 \%$ a $10 \%$. Martins \& Laugeni (2006) destacam que essa é a maneira mais correta para se determinar o número de vezes que a operação deve ser cronometrada.

\section{Tempo Médio (TM)}

O tempo médio (TM) dos tempos cronometrados pode ser calculado através do tempo normal da operação. Segundo Barnes (1977), o tempo normal para uma operação não contém tolerância alguma. É aquele requerido por uma operação onde não levamos em conta interrupções nem condições operacionais especiais. Ele acrescenta às cronometragens eficiência do operador, indicando em quanto tempo a operação deve ser executada. Sendo assim temos:$$
T M=T N \times E F / 100
$$

Onde:

TM = Tempo médio;

$\mathrm{TN}=$ Tempo normal

$\mathrm{EF}=$ Eficiência do operador em porcentagem

\section{Fator de Tolerância (FT)}

É preciso analisar e prever interrupções no trabalho para que possam ser atendidas as necessidades pessoais, para aliviar os efeitos da fadiga no trabalho e proporcionar um bom descanso. Segundo Martins \& Laugeni (2006), as tolerâncias também podem ser calculadas em função dos tempos de permissão que a empresa se dispõe a conceder. Após a análise e soma das porcentagens ( $p$ ) calculamos o fator de tolerância (FT), que pode ser calculado usando:

$$
F T=\frac{100}{100}-p
$$

O fator de tolerância incorpora ao tempo normal da operação este período em que não há produção (tempo permissivo). Contudo, como podemos observar, é um fator que pode variar bastante conforme as condições a que o trabalhador fica exposto e que tipo de trabalho ele realiza.

\section{Tempo Padrão}

Na visão de Murdel (1966), tempo padrão é uma função da quantidade de tempo necessário para desenvolver uma unidade de trabalho, usando um método e equipamentos dados, sob certas condições de serviço, por um trabalhador que possua uma quantidade específica de habilidade na atividade e que utilizará dentro de período de tempo, seu esforço físico para desenvolver tal trabalho sem efeitos prejudiciais. De acordo com Graeml \& Peinado (2007), o tempo padrão (TP) é calculado multiplicando-se o tempo normal por um fator de tolerância para compensar o período que o trabalhador, efetivamente, não trabalha. 0 cálculo pode ser assim expresso: 


\section{$T P=T N \times F T$}

Porém para o caso analisado será usado um conceito misto de takt time e tempo padrão onde a formula será:

$$
T P=\frac{3600}{T N} \times F T
$$

Tempo Takt (takt Time)

A palavra alemã Takt serve para designar o compasso de uma composição musical, tendo sido introduzida no Japão nos anos 30 com o sentido de "ritmo de produção", quando técnicos japoneses estavam a aprender técnicas de fabricação com engenheiros alemães. O takt time é definido a partir da demanda do mercado e do tempo disponível para produção, é o ritmo de produção necessário para atender a demanda.

Matematicamente, resulta da razão entre o tempo disponível para a produção e o número de unidades a serem produzidas (SHOOK, 1998).

Iwayama (1997) afirma que o Takt time é o tempo alocado para a produção de uma peça ou produto em uma célula ou linha. A ideia de "alocação" de um tempo para produção pressupõe, naturalmente, que alguém "aloca"; o Takt Time não é um dado absoluto, mas sim determinado.

Para Rother e Shook (2003), o Takt Time é definido pela equação a seguir:

$$
\text { TAKT TIME }=\frac{\text { TEMPO DISPONÍVEL POR TURNO }}{\text { DEMANDA DO CLIENTE POR TURNO }}
$$

\section{CÉLULA DE MANUFATURA (CM)}

O layout tradicional, ainda amplamente utilizado nas empresas, é o funcional ou por processo, os quais apresentam grande movimentação de materiais e pessoas, ocasionados por fluxos de materiais e roteiros de produção bastante diversificados (CORREA; GIANESI; CAON, 2001). Para Martins e Laugeni (1998), nesse tipo tradicional de layout, os equipamentos e processos relacionados são posicionados em uma mesma área, bem como as operações e montagens.

Para Tubino (1999), há ainda o fato de que há baixo envolvimento dos trabalhadores com todas as etapas do processo produtivo, ficando cada um deles restrito à sua área de atuação.

Por conta disso, o arranjo físico utilizado pelas empresas que adotam o Pensamento Enxuto em sua produção é o layout Celular (FURTADO DA SILVA, 2009).

Uma célula é descrita como um arranjo de equipamentos, materiais e operadores, em que as etapas do processo estão próximas e são sequenciais e processadas em fluxo contínuo (ALMEIDA, 2006).

Uma célula de manufatura é um agrupamento de máquinas ou postos de trabalho no formato geralmente de um " $U$ " dedicadas a uma determinada família 
de produtos com processos de fabricação semelhantes, isto é, utilizam os processos de fabricação das mesmas máquinas e na mesma sequência de processamento.

O layout físico de uma célula em "U", como mostrado na Figura 2, é o mais difundido e utilizado, apesar de existirem outras formas de arranjo físico com o mesmo conceito envolvido (ROTHER; HARRIS, 2002).

Figura 2 - Exemplo de esquema de layout celular

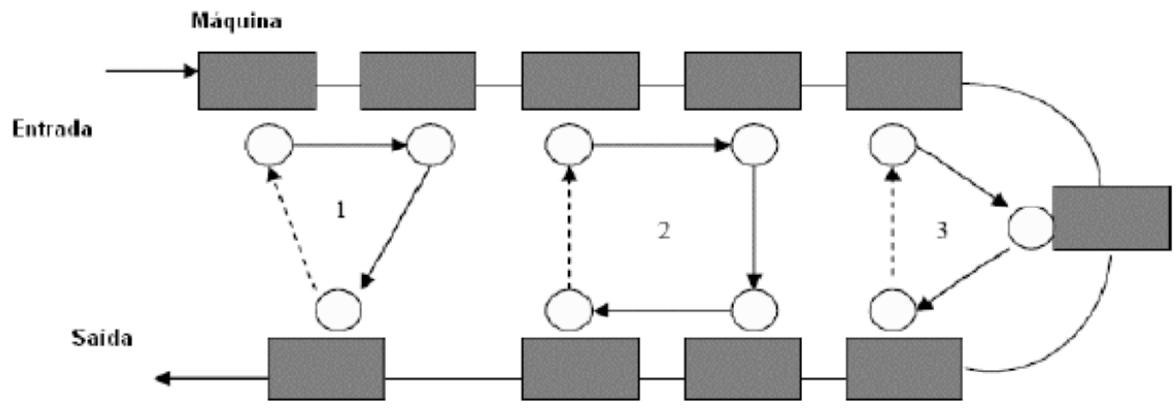

Fonte: Monden (1998)

Como vantagens e motivos para utilização desse arranjo físico podem ser citadas: eliminação do estoque em processo e vantagens relacionadas à qualidade, visto que se torna mais rápida a percepção de defeitos e peças não-conformes, pelo fato de que o consumo das peças pelo processo seguinte é praticamente instantâneo (SILVA, 2007).

\section{BALANCEAMENTO DE FLUXO E CARGA (BFC)}

Para sua implantação certos cuidados devem ser observados, como exemplo a redução dos tempos de setup das máquinas ou postos de trabalho, o aumento da confiabilidade das máquinas e equipamentos, o treinamento dos operadores para torná-los multifuncionais, entre outros fatores. Tudo isto para que seja possível a obtenção das vantagens relacionadas.

O mais importante das células de manufatura não é a disposição física em si, mas sim como estabelecer o fluxo contínuo de peças através dela. Para isso é necessário um bom balanceamento das atividades dentro da célula, o que chamaremos de Balanceamento de Fluxo e Carga.

-Discutir com os envolvidos o tipo de trabalho a ser executado, procurando obter a colaboração dos encarregados e operadores do setor;

-Definir o método e dividir a operação em elementos;

-Treinar os operadores para que desenvolvam o trabalho de acordo com o método estabelecido;

-Anotar na folha de observação todos os dados necessários;

-Elaborar um desenho esquemático da peça e do local de trabalho;

-Realizar a cronometragem; 
-Verificar se o $\mathrm{n}^{\circ}$ de ciclos cronometrados foi suficiente (folha de observação) e realizar mais cronometragens se necessário;

-Determinar o tempo padrão da operação (folha de observação);

-Elaborar a Folha de Balanceamento de Fluxo e Carga.

Os elementos de uma operação são as partes em que a operação pode ser dividida. Esta divisão tem por finalidade a verificação do método de trabalho e deve ser compatível com a obtenção de uma medida precisa, tomando-se o cuidado de não dividir a operação de muitos ou em demasiadamente poucos elementos.

\section{MÉTODO DE PESQUISA}

A pesquisa realizada teve caráter quantitativo, pois considera que tudo pode ser quantificável, o que significa traduzir em números opiniões e informações para classificá-las e analisá-las. Requer o uso de recursos e de técnicas estatísticas apresentados no referencial teórico.

Por questões sigilosas a empresa foi chamada de Indústria Moveleira. A inovação, o design, a tecnologia e, acima de tudo, o capital humano marcam a construção desta empresa.

A Indústria Moveleira está, hoje, presente em mais de 120 países. Respeitar as diferenças culturais de cada um desses lugares é um dos princípios de negócios da Indústria Moveleira. Nesse sentido, mescla seus valores internos com os códigos locais, o que gera um clima organizacional coeso e harmônico em todas as suas unidades, no Brasil e no mundo.

O presente trabalho foi realizado em uma unidade situada no Norte do Brasil, no estado de Belém do Pará. A unidade conta com 38.958,00 $\mathrm{m}^{2}$ de área construída, emprega aproximadamente 400 funcionários, utiliza a madeira como matéria-prima para produzir mais de 1.200 produtos, dentre esses produtos podemos, o foco desse trabalho será na linha de utilidades, porém existem outros.

Com relação aos conceitos de Produção Enxuta, foi iniciado a aproximadamente 10 anos um programa com o objetivo de implementar um modelo de gestão da produção que levasse a reduzir perdas, a sincronizar processos, reduzir custos operacionais, melhorando a produtividade e a competitividade. Algumas ferramentas foram utilizadas ao logo dessa jornada.

Após 10 anos e passando por momentos de turbulência nos cenários estratégicos, tanto no ambiente interno quanto no externo, a semente Lean ainda estava presente no cotidiano da empresa, era evidente que estava perdendo a força e os indicadores mostravam certa estagnação.

Com o objetivo de manter o Pensamento Enxuto, a empresa decidiu renovar e reforçar os conceitos a fim de perpetuar a filosofia. Deu-se início a novos projetos. Com isso novas ferramentas foram utilizadas e serão apresentadas no seguinte trabalho, como: análise a partir dos conceitos de Takt Time, MFV, CM e BFC. A Figura 1 mostra a casa e com ela todos os conceitos que a empresa utiliza para perpetuar o pensamento enxuto. 


\section{DELINEAMENTO E ETAPAS DE PESQUISA}

Com o intuito de obter dados relevantes para este trabalho, foi realizada uma participação no comitê de planejamento e controle de processos que pertence a Industrial Moveleira, esse comitê está diretamente relacionado à criação de células. A data para coleta de dados iniciou-se aproximadamente a partir do dia $15 / 04$ até aproximadamente $3 / 11$. Sendo que todos os dados foram coletados e medidos durante a execução do projeto através de cronômetros, planilhas e o próprio sistema da empresa, com presença parcial até a fase de conclusão da célula em questão. A Célula do Produto (Fruteira) para apresentar o uso das ferramentas e logo a seguir a forma de como é realizada a análise e o desenvolvimento das mesmas com base na produção enxuta.

Antes de tudo, foi definido qual o objetivo e as premissas para o desenvolvimento desse trabalho. O Pensamento Enxuto parte do princípio da formação de equipes multidisciplinar, sendo indicado um Líder, um Colíder e demais colaboradores. Formada a equipe de criação de células, todos os membros devem passar por um treinamento para reforçar os conceitos de takt time, $\mathrm{CM}$, Lean, MFV e BFC.

Logo após o treinamento, teve início a fase de levantamento de dados. A primeira ação é identificar o MFV do produto no sistema que passa na célula. $\mathrm{O}$ MFV da Fruteira informa a quantidade de operações, a descrição das operações presentes para a fabricação do produto, o tempo de cada operação, a quantidade que é produzida por hora, o número de funcionários que executa cada operação, o número de máquinas que é utilizado para executar cada operação, e o custo de cada operação que será nosso parâmetro para comparar o antes e o depois. A Figura 3 ilustra essas informações do levantamento antes das ferramentas Lean.

Figura 3 - Mapeamento de fluxo de valor da célula de produção da fruteira

\begin{tabular}{|l|r|r|r|r|r|}
\hline $\begin{array}{l}\text { Operações Analisadas e cronometradas } \\
\text { Descrição da operação }\end{array}$ & Qtde func & Qtde maq & TP & Tempo (s) & QTDE UP \\
\hline EMBALAR & 2,00 & 1,00 & 48 & 60 & 2,50000 \\
\hline COLAR ETIQUETAS & 1,00 & 1,00 & 72 & 40 & 0,83333 \\
\hline COLOCAR BUCHAS E RODAS & 1,00 & 1,00 & 115 & 25 & 0,52083 \\
\hline PARAFUSAR SUPORTE & 2,00 & 1,00 & 52 & 55 & 2,29167 \\
\hline MONTAR & 2,00 & 1,00 & 48 & 60 & 2,50000 \\
\hline INSPECIONAR & 0,50 & 1,00 & 52 & 55 & 0,57292 \\
\hline COLOCAR COMPONENTE & 0,50 & 1,00 & 52 & 55 & 0,57292 \\
\hline ABRIR CAVAS/FURAR & 1,00 & 1,00 & 115 & 25 & 0,52083 \\
\hline FRESAR ESPIGA & 0,50 & 1,00 & 115 & 25 & 0,26042 \\
\hline QUEBRAR CANTO & 0,50 & 1,00 & 115 & 25 & 0,26042 \\
\hline PREMONTAR \& PRENSAR & 2,00 & 1,00 & 115 & 25 & 1,04167 \\
\hline ABRIR RASGO & 0,50 & 1,00 & 115 & 25 & 0,26042 \\
\hline LIXAR TOPO & 0,50 & 1,00 & 115 & 25 & 0,26042 \\
\hline ENVERNIZAR & 4,00 & 1,00 & 169 & 85 & 1,42000 \\
\hline FURAR & 1,00 & 1,00 & 72 & 40 & 0,83333 \\
\hline COLOCAR BUCHA & 1,00 & 1,00 & 288 & 10 & 0,20833 \\
\hline COLOCAR CAVILHA & 1,00 & 1,00 & 240 & 12 & 0,25000 \\
\hline ABRIR RASGO & 0,50 & 1,00 & 206 & 14 & 0,14583 \\
\hline MARCAR & 0,50 & 1,00 & 180 & 16 & 0,16667 \\
\hline & & & & 15,42 \\
\hline
\end{tabular}

Fonte: Autoria própria (2017) 
De acordo com a Figura 3, pode-se observar através do MFV da Fruteira todas as operações que o produto sofre para poder ser expedido para o cliente final através da operação de embalagem.

As operações destacadas por uma cor mais escuras na figura 3 são as operações que podem ser alteradas ou modificadas sem prejudicar a estrutura ou a aparência do produto final. Se as outras operações do mapeamento de fluxo de valor forem alteradas, o produto perderá mercado, pois se mudar as características ganhadoras de pedidos, prejudicará a produção e venda do produto. Essas foram às condições impostas pelo diretor de vendas da empresa.

A operação que determina a quantidade produzida por hora é a embalagem (a operação que leva maior tempo dentre as outras é chamada de operação "gargalo", nesse caso o gargalo é a operação de Montar e como a operação final é a Embalagem o tempo é replicado).

Descrevendo a operação de embalagem temos: dois funcionários para embalar em uma máquina, que gera um produto, a relação se lê "a operação está dois para um", o tempo padrão da operação é 48 , ou seja, em uma hora é produzido/embalado 48 produtos, o tempo para realizar a operação de embalagem por unidade de produto é de 60 segundos e a quantidade de UP gerada para a produção desse produto através da operação de embalagem é 2,5 esse valor representa o custo dessa operação para a empresa.

Após análise das operações os tempos deverão ser analisados e cronometrados, para executar essa atividade duas ferramentas fundamentais foram utilizadas, é a folha de observações, nela contém, as informações de operações, número de funcionários, número de máquinas, gargalo(s), número de cronometragens (N), o tempo médio (TM), o fator de tolerância (FT) e o próprio tempo padrão (TP).

Mediante o estudo de tempos, os conceitos de células e de balanceamento são usados na mesma folha, com espaço para esboçar o layout adequado para aquelas operações que podem ser ou não colocadas em forma de célula e o espaço para balancear as operações que compõem a célula. A Figura 4 ilustra a folha de observações. 
Figura 4 - Folha de observações

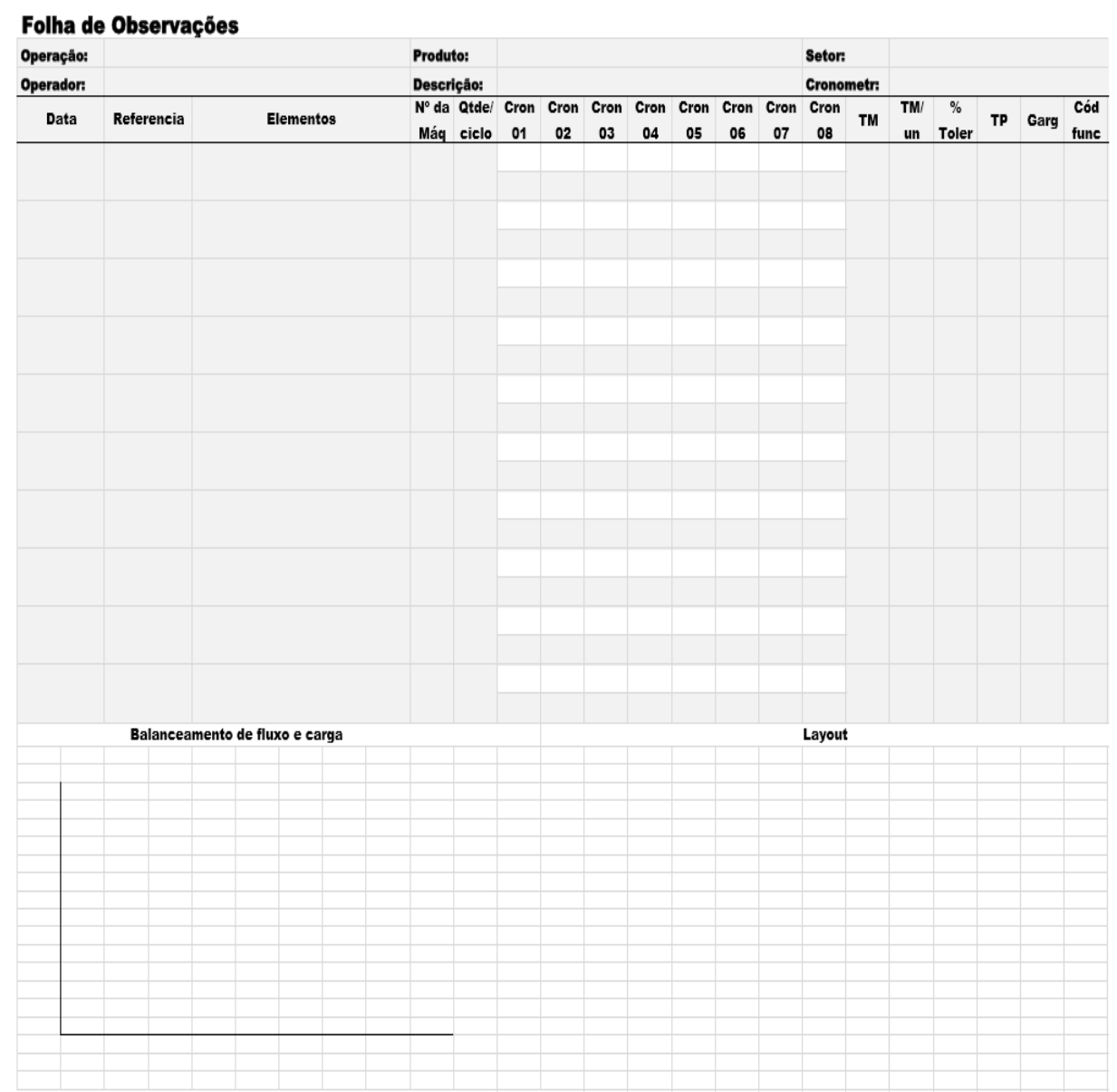

Fonte: Autoria própria (2017)

Para se utilizar a folha de observações alguns valores precisam ser levantados, como TM, FT, N e TP.

Para obter o número de observações (N) levando em consideração a variação das operações analisadas usando a formula (1) onde:

$$
\begin{aligned}
& Z=1,96 ; \\
& S=0,00240512264162304 ; \\
& A=10 ; \\
& X=60 ; \\
& \text { Logo temos: } N=8 .
\end{aligned}
$$

Para obter o tempo médio (TM) de cada operação com um colaborador padrão e usando a formula (2), onde:

$$
\begin{aligned}
& \mathrm{TN}=60 \\
& \mathrm{EF}=100
\end{aligned}
$$

Logo temos: $\mathrm{TM}=60$. 
Para obter o fator de tolerância (FT) padrão da empresa, foi levando em consideração todas as possíveis perdas de produtividade, tais como, fadiga, ergonomia, necessidades fisiológicas entre outros. Usando a formula (3) onde:

$P=20 \%$ ou 0,2

Logo temos: $\mathrm{FT}=80 \%$ ou 0,8 .

De posse desses dados ainda na operação de embalagem, podemos calcular o tempo padrão (TP) da operação através da formula (4), onde:

$$
\begin{aligned}
& \mathrm{TM}=67 ; \\
& \mathrm{FT}=0,8 ;
\end{aligned}
$$

Logo temos: TP $=48$ peças por hora.

Com a utilização da folha de observações, a criação de células é a próxima etapa. Para esse produto serão criadas duas células de manufatura, onde uma será de formato " $U$ ", por ser apenas 1 funcionário, a disposição dos equipamentos que melhor é nesse formato. E a outra será de formato "L", por conta do espaço e a saída do material pela lateral da célula. A CM de formato em "U" será a de componentes produzidos para atender a célula em formato "L" que será a célula de embalagem. A Figura 3 mostra as operações desse produto, por motivos sigilosos não serão apresentados nesse trabalho os componentes que esse item precisa.

Porém a ordem de visualização das atividades segue de baixo para cima, conforme Figura 5, ou seja, para se montar a Fruteira devem-se ter componentes que são montados separadamente, porém paralelamente.

Figura 5 - Mapa de fluxo de valor das operações obedecendo à ordem de produção baixo para cima

\begin{tabular}{|l|r|r|r|r|r|}
$\begin{array}{l}\text { Operações Analisadas e cronometradas } \\
\text { Descrição da operação }\end{array}$ & Qtde func & Qtde maq & TP & Tempo (s) & QTDE UP \\
\hline EMBALAR & 2,00 & 1,00 & 48 & 60 & 2,50000 \\
\hline COLAR ETIQUETAS & 1,00 & 1,00 & 72 & 40 & 0,83333 \\
\hline COLOCAR BUCHAS E RODAS & 1,00 & 1,00 & 115 & 25 & 0,52083 \\
\hline PARAFUSAR SUPORTE & 2,00 & 1,00 & 52 & 55 & 2,29167 \\
\hline MONTAR & 2,00 & 1,00 & 48 & 60 & 2,50000 \\
\hline INSPECIONAR & 0,50 & 1,00 & 52 & 55 & 0,57292 \\
\hline COLOCAR COMPONENTE & 0,50 & 1,00 & 52 & 55 & 0,57292 \\
\hline ABRIR CAVAS/FURAR & 1,00 & 1,00 & 115 & 25 & 0,52083 \\
\hline FRESAR ESPIGA & 0,50 & 1,00 & 115 & 25 & 0,26042 \\
\hline QUEBRAR CANTO & 0,50 & 1,00 & 115 & 25 & 0,26042 \\
\hline PREMONTAR \& PRENSAR & 2,00 & 1,00 & 115 & 25 & 1,04167 \\
\hline ABRIR RASGO & 0,50 & 1,00 & 115 & 25 & 0,26042 \\
\hline LIXAR TOPO & 0,50 & 1,00 & 115 & 25 & 0,26042 \\
\hline ENVERNIZAR & 4,00 & 1,00 & 169 & 85 & 1,42000 \\
\hline FURAR & 1,00 & 1,00 & 72 & 40 & 0,83333 \\
\hline COLOCAR BUCHA & 1,00 & 1,00 & 288 & 10 & 0,20833 \\
\hline COLOCAR CAVILHA & 1,00 & 1,00 & 240 & 12 & 0,25000 \\
\hline ABRIR RASGO & 0,50 & 1,00 & 206 & 14 & 0,14583 \\
\hline MARCAR & 0,50 & 1,00 & 180 & 16 & 0,16667 \\
\hline
\end{tabular}

Fonte: Autoria própria (2017) 
A primeira célula a ser montada será chamada de célula de componentes, esta célula fornece componentes para a célula de embalagem. A Figura 5 mostra as operações da célula de componentes.

Criada a CM uma nova folha de observações é utilizada a fim de balancear e distribuir as operações para eliminar ou reduzir gargalos com base nos conceitos do pensamento enxuto sempre trabalhando em cima das sete grandes perdas.

As cinco operações possuem quatro funcionários como mostra na Figura 5, furar um funcionário para uma máquina, colocar bucha um funcionário para uma máquina; colocar cavilha um funcionário para uma máquina; abrir rasgo e marcar $1 / 2$ funcionário para uma máquina, lê se "meio para um" (isso significa que um funcionário executa duas operações ou opera duas máquinas). O TP dessas operações será distribuído na forma de célula, ou seja, a operação gargalo ou a operação que apresentar maior TP, nesse caso é a marcar, será replicado o tempo dessa operação para as outras operações da célula, a quantidade por hora então será 180 peças.

Como conceito é eliminar processos que não agregam valor ao produto suas operações foram eliminadas, a de Furar TP $=72$ e Colocar Cavilha $=240$. Estas operações foram eliminadas pelo fato do produto não precisar de cavilhas, pois a cavilha dava segurança para que os componentes não girassem, porém com base em testes realizados na empresa, concluiu-se que sem as cavilhas esse problema não ocorreria. Essa melhoria se enquadra na categoria Kaizen, para o processo usava-se um funcionário para fazer o furo da cavilha e outro para coloca-la.

Eliminando esses funcionários dessa operação a nova célula precisará de apenas um funcionário que executará as três operações restantes, com o conceito de célula, com layout ajustados e com os materiais e equipamentos estão mais próximos do operador, o tempo de ciclo das operações caiu para 8 segundos e o TP é de 360 peças por hora, ou seja, a cada 8 segundos um componente é fabricado. A figura 6 mostra a configuração do Layout dessa célula e onde se devem colocar os materiais.

Figura 6 - Layout da célula de componentes em formato “ $U$ ”

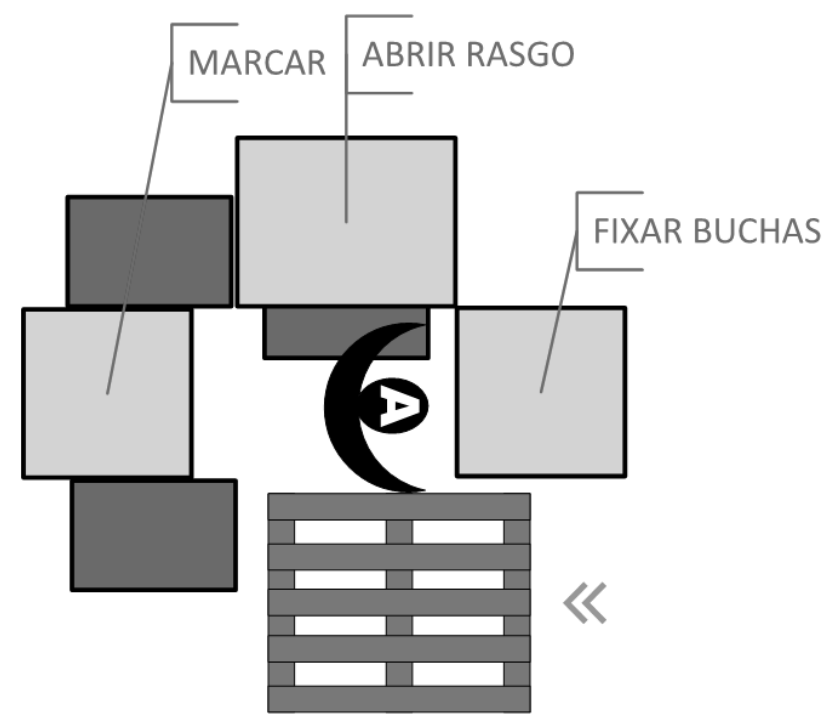

Fonte: Autoria própria (2017) 
Após a conclusão da célula de componentes a próxima célula será a de embalagem, a análise das operações foi feita da mesma maneira, o MFV foi analisado e os tempos coletados através da folha de observações mostraram que as operações estavam desbalanceadas.

Com o balanceamento da célula e com a análise minuciosa das operações, a operação que não agregava valor foi eliminada, que é o caso da operação de inspeção que apresentava TP $=52$. Como a operação era $1 / 2$ funcionário para uma máquina, então mais uma vez o balanceamento foi feito para se obter a configuração ideal para reduzir os gargalos. A Figura 7 mostra o MFV após as melhorias e mudanças através do pensamento enxuto.

Figura 7 - Mapa de fluxo de valor da Fruteira após melhorias

\begin{tabular}{|l|r|r|r|r|r|}
\hline \multicolumn{1}{|c|}{ Descrição da operação } & Qtde func & Qtde maq & TP & Tempo (s) & QTDE UP \\
\hline EMBALAR & & & & & \\
\hline COLAR ETIQUETAS & 1,00 & 1,00 & 56 & 51 & 1,06250 \\
\hline COLOCAR BUCHAS E RODAS & 1,00 & 1,00 & 56 & 51 & 1,06250 \\
\hline PARAFUSAR SUPORTE & 1,00 & 1,00 & 56 & 51 & 1,06250 \\
\hline MONTAR & 2,00 & 1,00 & 56 & 51 & 2,12500 \\
\hline COLOCAR COMPONENTES & 2,00 & 1,00 & 56 & 51 & 2,12500 \\
\hline ABRIR CAVAS/FURAR & 1,00 & 1,00 & 56 & 51 & 1,06250 \\
\hline FRESAR ESPIGA & 1,00 & 1,00 & 115 & 25 & 0,52083 \\
\hline QUEBRAR CANTO & 0,50 & 1,00 & 115 & 25 & 0,26042 \\
\hline PREMONTAR \& PRENSAR & 0,50 & 1,00 & 115 & 25 & 0,26042 \\
\hline ABRIR RASGO & 2,00 & 1,00 & 115 & 25 & 1,04167 \\
\hline LIXAR TOPO & 0,50 & 1,00 & 115 & 25 & 0,26042 \\
\hline ENVERNIZAR & 0,50 & 1,00 & 115 & 25 & 0,26042 \\
\hline COLOCAR BUCHA & 4,00 & 1,00 & 169 & 85 & 1,42000 \\
\hline ABRIR RASGO & 0,33 & 1,00 & 360 & 8 & 0,05556 \\
\hline MARCAR & 0,33 & 1,00 & 360 & 8 & 0,05556 \\
\hline
\end{tabular}

Fonte: Autoria própria (2017)

Feito isso a nova célula é concluída, as operações que se encontram em células possuem o mesmo tempo padrão da operação gargalo. Nesse caso a operação de gargalo é parafusar os suportes com TP $=51$, ou seja, 56 produtos serão embalados pela célula.

Após a fase de análise e desenvolvimento de técnicas, a célula será padronizada de acordo com o BFC que mostra a padronização das operações, o tempo padrão das mesmas e a posição das máquinas e ou equipamentos necessários de acordo com o layout pré-determinado, conforme Figura 8. 
Figura 8 - Balanceamento de Fluxo e Carga BFC

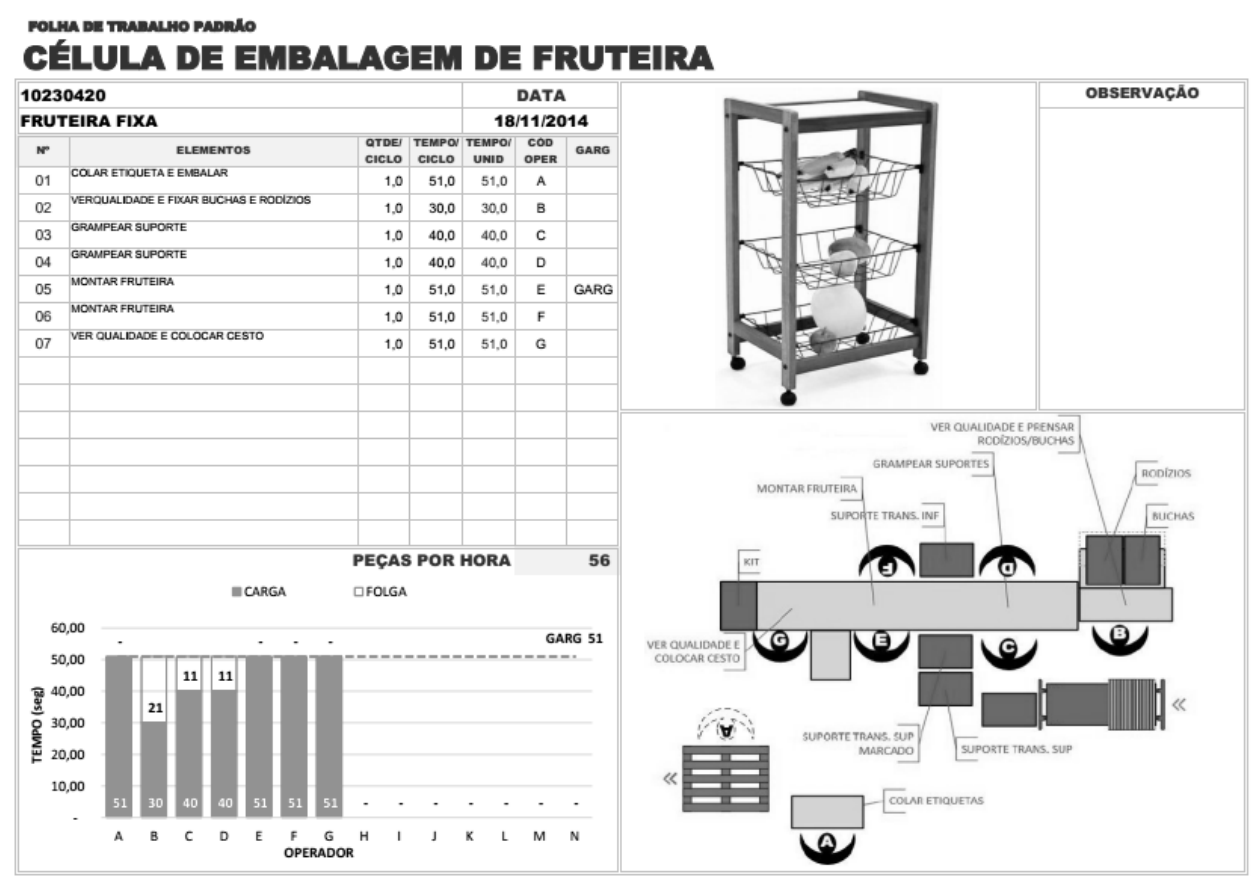

Fonte: Autoria própria (2017)

O presente tópico aborda como a pesquisa foi desenvolvida, os processos analisados, as ferramentas usadas, os custos de produção e seus tempos e os procedimentos para obtenção dos resultados.

Identificar os gargalos dos processos é de extrema importância, pois a partir da análise das operações pode-se definir quais decisões tomar e quais processos devem ser modificados ou até mesmo eliminados.

Nesse caso a embalagem é a operação gargalo do produto, ela limita a quantidade de produto a ser produzido por hora. Usando as técnicas de análise de TM, identificou-se que duas células deveriam ser criadas, uma foi em formato de " $U$ " e outra em formato de " $L$ ". A célula em " $U$ " fornece componentes para a célula em "L" embalar os produtos acabados.

Após a criação das células a ferramenta BFC foi usada para balancear as operações e distribuí-las, para assim reduzir a sobrecarga de trabalho de cada funcionário entre elas.

Com isso algumas atividades foram eliminadas, melhoradas ou modificadas. Assim a célula em " $U$ " que antes possuía 4 funcionários e produzia uma quantidade de 72 componentes por hora, passou a ter apenas 1 funcionário e produzir 360 peças por hora. Isso gerou uma redução no custo de produção de $90 \%$.

Já a célula de embalagem houve a redução de 1 funcionário e com suas atividades balanceadas e padronizadas, obteve aumento de 8 unidades embaladas por hora e redução de $29 \%$.

\section{RESULTADOS}

Depois de definida a equipe e cada membro receber o devido treinamento em células de manufatura, conceitos de produção puxada, estudo de tempos, foi dado 
início o período de preparação para os próprios supervisores controlarem a célula e não mais o comitê de processo da empresa. No decorrer desse período foram levantados dados, como, tempo de ciclo para saber se estava sendo atingidas as metas, foi implementado o quadro de sequenciamento de produção para controle visual.

\section{RESULTADO DA CÉLULA DE COMPONENTES}

Com relação à célula de componentes, comparando o antes e o depois da implantação das ferramentas lean, observa-se que antes funcionava com quatro funcionários para executar cinco operações e a partir da mudança apenas com um funcionário para executar as três operações restantes.

O custo de produção reduziu cerca de $89,61 \%$, pois o valor da UP antes das melhorias era de 1,60417 das cinco operações iniciais. Após as melhorias e com a redução de duas dessas operações como foi mencionado acima o valor de UP passou a ser 0,166667, e a espera foi eliminada.

A quantidade produzida por hora antes das mudanças era de TP $=72$ peças por hora, após a mudança o tempo padrão passou a ser TP =360 peças por hora usando a relação de pode-se chegar à conclusão que a produtividade da célula melhorou cerca de $80 \%$ para atender a demanda da célula de embalagem.

Tabela 1 - tabela da célula de componentes de ganhos comparando o antes e o depois da implantação das ferramentas lean

$\begin{array}{cccc}\text { Comparativo } & \text { Antes } & \text { Depois } & \text { Ganhos } \\ \text { Estágios com estoque ou espera } & 1,00 & - & 100 \% \\ \text { Qtde de funcionários } & 4,00 & 1,00 & 75 \% \\ \text { Quantidade produzida por hora } & 72,00 & 360,00 & 400 \% \\ \text { Tempo de produção por unidade } & 40,00 & 8,00 & 80 \% \\ \text { Quantidade produzida/ número de func. } & 10,00 & 8,00 & 20 \% \\ \text { Up's das operações estudadas } & 1,60 & 0,17 & 90 \%\end{array}$

Fonte: Autoria própria (2017)

\section{RESULTADO DA CÉLULA DE EMBALAGEM}

Como as operações não eram balanceadas antes da implantação do sistema existiam três estágios entre as operações de montar e inspecionar, e entre as operações de furar e colocar buchas na célula de componentes, isso fazia com que gerasse espera na célula de embalagem, após as melhorias esses estágios de espera foram eliminados.

Com relação à célula de embalagem comparando o antes e o depois da implantação das ferramentas lean, observa-se que antes funcionava com nove funcionários para executar sete operações e a partir da mudança com a redução de 1 funcionário que inspecionava e a distribuição da operação das operações, a célula ficou com oito funcionários.

O custo de produção reduziu cerca de $28,51 \%$, pois o valor da UP antes das melhorias era de 9,79167 das cinco operações iniciais. Após as melhorias e com a 
redução de duas dessas operações como foi mencionado acima o valor de UP passou a ser 8,500.

A quantidade produzida por hora antes das mudanças era de TP $=48$ peças por hora, após a mudança o tempo padrão passou a ser TP $=56$ peças por hora usando a relação de pode-se chegar à conclusão que a produtividade da célula melhorou cerca de $58 \%$.

Além disso, como não se havia controle na célula de embalagem, outros desperdícios foram encontrados e eliminados como mostra a tabela 1 e 2, como: superprodução, estoque e movimentações.

Tabela 2 - Tabela da célula de embalagem de ganhos comparando o antes e o depois da implantação das ferramentas lean

$\begin{array}{cccc}\text { Estágios com estoque ou espera } & \text { Antes } & \text { Depois } & \text { Ganhos } \\ \text { Qtde de funcionários } & 3,00 & - & 100 \% \\ \text { Tempo de produção por unidade } & 9,00 & 8,00 & 11 \% \\ \text { Quantidade produzida por hora } & 48,00 & 51,00 & 15 \% \\ \text { Quantidade produzida/ Número de func. } & 5,33 & 56,47 & 18 \% \\ \text { Up's das operações estudadas } & 9,79 & 7,41 & 58 \% \\ \text { Custo do produto } & 65,68 & 46,78 & 29 \% \\ \text { Custo por quantidade faturada (6 meses) } & \mathrm{R} \$ 78.090,61 & \mathrm{R} \$ 55.621,42 & \mathrm{R} \$ 22.469,19\end{array}$

Fonte: Autoria própria (2017)

\section{CONCLUSÕES}

Para que essas empresas possam atender e superar as expectativas de seus clientes, o processo de produção é de suma importância no sucesso das vendas. Existem vários princípios de produção enxuta que vêm sendo evolutivamente incorporados às organizações para ajudá-las a eliminar desperdícios, barateando assim custos de produção e elevando a qualidade dos produtos.

Com as ferramentas do sistema Lean e o pensamento enxuto, a empresa obteve ganhos em apenas um dos 1.200 produtos que fabrica. Portanto está claro que replicará os conceitos e ferramentas utilizadas para seus produtos existentes e para novos produtos. Com o objetivo de se tornar uma empresa enxuta, a mesma deve seguir à risca todas as estratégias abordadas nesse caso, tudo começa pelos princípios do pensamento enxuto dentro da organização e a conscientização do uso da filosofia.

O presente estudo iniciou-se quando a empresa passava por momentos delicados, porém os resultados agradaram tanto supervisores quanto diretores que apoiam e aprovam a política de produção enxuta na organização.

Alguns dos objetivos apresentados nesse caso são: a eliminação de desperdícios para a redução de custos de fabricação, facilitar o trabalho do operador reduzindo assim o custo do mesmo, reduzir o ciclo dos produtos fazendo com que a linha conseguisse abastecer somente o necessário a embalagem, tornando a produção puxada. 
O Pensamento Enxuto aplicado na indústria moveleira teve como objetivo principal a análise de mapeamento de fluxo de valor e a redução dos custos de fabricação que consequentemente reduz o custo do produto. A redução de custos de fabricação eleva a produtividade sem afetar a qualidade de vida dos funcionários e facilita ainda mais a saída do produto, já que o mesmo chegará aos clientes custando menos.

A redução do custo dos produtos com o uso de ferramentas Lean é uma das diversas estratégias adotadas, pois a variabilidade e as exigências do mercado são complexas. Para responder prontamente às variações de demanda e de configuração dos produtos oferecidos, deve-se basear fundamentalmente na qualidade dos produtos e na flexibilidade da produção existente da indústria.

Para continuar desfrutando desses ganhos, a empresa deve sempre demonstrar o uso de todas as ferramentas e conceitos. Essa conscientização é muito importante, criar cartazes mostrando os resultados com o uso das ferramentas como a empresa já faz, é uma excelente estratégia de expor os resultados obtidos. É de a natureza humana deixar certas coisas de lado, porém para a empresa ficou claro que o pensamento enxuto traz benefícios excelentes.

Com o incentivo aos Kaizen, a empresa continua buscando vantagens competitivas no mercado, pois de acordo com a definição dessa ferramenta, a empresa deve estar em constante busca por melhorias. Planejar, definir metas, os métodos para alcança-los, treinar e checar são passos importantes e é uma excelente estratégia. O uso da ferramenta PDCA em conjunto com A3 para solução de problemas pode trazer vantagens satisfatórias para qualquer empresa que busque melhorar seus processos eliminando a causa raiz de seus desperdícios quais quer que sejam. 


\title{
Lean system for optimization of resources in a furniture industry: case study with focus on the lean production tools
}

\author{
ABSTRACT
}

With the increasingly demanding market, the industries must be suitable to serve its customers with quality and speed. To stay on competitively market their concepts and philosophies must be renewed. Considering the changing scenarios of organizations in general, the challenge is an ally of the rival's technological agility, for that, it should have an adaptive scenario for several functions, because to develop efficient systems, improve productivity, set standards and increase the service level are some of the differential to stay on market. The purpose of the case presented is to demonstrate the benefits of Lean Thinking applied in a lumber industry. The methodology consists in collecting data in a quantitative way, with this, check the use of the tools and what they can add in production processes. This consists of eliminating waste, reducing production costs and standardizing process operations. Some of the improvements obtained with the study are: all stops for stock were eliminated making the process follow a continuous flow, the number of employees per cell in one of them went from 4 to 1 , the elimination of operations that do not add value to the product as: Peg and drill, reduction of production cost by $29 \%$ and increase of the quantity produced per hour by $18 \%$.

KEYWORDS: Lean Thinking. Manufacturing Cells. Value Stream Mapping. 


\section{REFERÊNCIAS}

ALMEIDA, J. A. R. Uma visão geral da mentalidade enxuta, conceitos e ferramentas. São Carlos, 2006.

BARBOSA, F. G. Melhoria de Processo Produtivo pela aplicação de conceito lean: um estudo de caso. (Trabalho de Conclusão de curso) - Escola de Engenharia de São Carlos, Universidade de São Paulo, 2011.

BARNES, R. M. Estudo de Movimentos e de Tempos: projeto e medida do trabalho. 6. ed. São Paulo: Edgard Blüchen, 1977

BELHOT, R. V. Metodologia de Pesquisa em Engenharia de Produção. Escola de Engenharia de São Carlos, Universidade de São Paulo. 2004.

BNDES Setorial, Rio de Janeiro, n. 15, p. 83-96, mar. 2002.

CAMPANHOLA. C. Estudo prospectivo setorial - Móveis. Panorama setorial: cadeia moveleira. Bento Gonçalves: MOVERGS, Nov. 2008.

CARDOZA, E., CARPINETTI, L., 2005. Indicadores de Desempenho para o Sistema de Produção Enxuto. Revista Produção, v. 5, n. 2, pp.2-7. crossref

CORRÊA, H. L.; GIANESI, I. G. N.; CAON, M. Planejamento, Programação e Controle da produção. MRP II / ERP - Conceitos, uso e implantação. 4aedição, Atlas, 2001.

DOBLER, D. W.; BURT, D. N. Purchasing and Supply Management: Text and Cases. 6. ed. USA: Tata McGraw-Hill, 1996.

FURTADO DA SILVA, A. S. Avaliação de práticas e performance de manufatura enxuta, via Benchmarking, para diagnostico da indústria de confecções. Tese (Doutorado) - Universidade federal de Santa Catarina, Florianópolis. 2009. 315p.

GHINATO, P. Sistema Toyota de Produção- mais do que simplesmente Just in Time. Revista Produção, v. 5, n. 2, p. 169-190, 1995. crossref

GODINHO FILHO, M.; FERNANDES, F. C. Manufatura Enxuta- Uma Revisão que classifica e analisa os trabalhos apontando perspectivas de melhorias futuras. Gestão \& Produção, São Carlos, v.11, n.1, p. 1-19. 2004. crossref 
HANASHIRO, A. P. Proposta de Modelo de gestão do Conhecimento no piso de Fábrica: Estudo de caso de Kaizen em empresa do setor automotivo. Tese (mestrado) - Universidade Federal do Paraná. 2005.

HYER, N.; WEMMERLOV, U. Cell Manufacturing: the hard part is to get people in the step with the program. Engineering Management, march, 2004.

IMAI, M. Kaizen: A estratégia para o sucesso competitivo. 3a Edição, São Paulo: Instituto de Movimentação e armazenagem de Materiais - IMAM. 1990.

LÉXICO LEAN. Glossário ilustrado para praticantes do pensamento lean. São Paulo: Lean Institute Brazil, v.1.0, 2003. 97p.

LIKER, J. K. O Modelo Toyota:14 princípios de gestão do maior fabricante do mundo. PortoAlegre: Bookman. 2005

LIKER, J. K.; MEYER, D. Modelo Toyota - Manual de Aplicação: Um Guia Prático Para a Implementação dos 4Ps da Toyota. Porto Alegre: Bookman, 2007.

MACHADO, R. L., HEINECK, L. F. M. "Estratégias de Produção para a Construção Enxuta".

MARTINS, P. G. \& LAUGENI, F. P. Administração da Produção. São Paulo: Saraiva 1998.

MARTINS, P. G. \& LAUGENI, F. P. Administração da Produção. 2. Ed. São Paulo: Saraiva, 2006.

MOREIRA, D. Administração da Produção e Operações. São Paulo: Cengage Learning, 2009.

OHNO, T. O Sistema Toyota de Produção - além da produção em larga escala. Porto Alegre: Artes Médicas, 1997.

PEINADO, J. \& GRAEML, A. R. Administração da produção: operações industriais e de serviços. Curitiba: Unicenp, 2007.

PEREIRA DA SILVA, L. M. Avaliação do desempenho em empresas que adotam a produção enxuta como escolha estratégica Dissertação (Mestrado) - Escola de Engenharia, Universidade Federal do Rio Grande do Sul, Porto Alegre, 2006. 99p. 
RASTEIRO, G. Estudo sobre a aplicação da tecnologia RFID em sistemas de Kanban eletrônico. (Trabalho de Conclusão de Curso) - Escola de Engenharia de São Carlos, USP, São Carlos, SP, Brasil. 2009.

RENTES, A. F. Desenvolvimento de Sistemas de Produção Enxuta. Escola de Engenharia de São Carlos, Universidade de São Paulo, 2006.

RIANI, A. M. O Lean Manufacturing aplicado na Becton Dickinson. (Monografia de conclusão de curso) - Universidade Federal de Juiz de Fora, Minas Gerais, 2006.

ROTHER, M.; SHOOK, J. Leaning to See - Value Stream Mapping add Value and Eliminate Muda, The Lean Enterprise Institute, Ma, USA, 1998.

ROTHER, M.; SHOOK, J. Aprendendo a enxergar.São Paulo: Lean Institute Brasil, 2003.

ROTHER, M.; HARRIS, R. Criando fluxo contínuo. São Paulo: Lean Institute Brasil, 2002.

RUSSOMANO, V. H. PCP: Planejamento e Controle da Produção. 4. ed. São Paulo: Pioneira, 2000.

SAIA, R. O lean manufacturing aplicado em ambientes de produção engineer to order. (Trabalho de conclusão de curso) - Escola de Engenharia de São Carlos, Universidade de São Paulo, 2009.

SCOTELANO, L. S. Aplicação da filosofia kaizen e uma investigação em uma empresa automobilística. Ver. FAE, Curitiba, v.10, n.2. 2007.

SHINGO, S. O Sistema Toyota de Produção do ponto de vista da Engenhara de Produção. 2a edição. Porto Alegre. Bookman Companhia Editora. 1996.

SHOOK, J. Gerenciamento para o aprendizado. Lean Institute Brasil, 2008.

SILVA, Edna Lúcia da. Metodologia da pesquisa e elaboração de dissertação/Edna Lúcia da Silva, Estera Muszkat Menezes. - 4. ed. rev. atual. Florianópolis: UFSC, 2005 
SILVA, T. F. A. Estudo sobre Sistema de Medição de desempenho baseado nas ferramentas da Produção Enxuta. Trabalho de Conclusão de Curso - Escola de Engenharia de São Carlos - Universidade de São Paulo, 2007.

SLACK, N.; CHAMBERS, S.; JOHNSTON, R. Administração da Produção - 2a edição. 7ạ reimpressão: 2007. São Paulo: Atlas. 1997.

SLACK, N. Administração da Produção. Edição compacta. São Paulo: Atlas. 2006.

STEFANELLI, P. (2007). Utilização da contabilidade dos ganhos como ferramenta para tomada de decisão em um ambiente com aplicação dos conceitos de Produção Enxuta. Trabalho de Conclusão de Curso - Escola de Engenharia de São Carlos - USP, 2007.

SOCIEDADE BRASILEIRA DE SILVICULTURA. SBS. Setor florestal brasileiro. Disponível em: <http://www.sbs.org.br/estatisticas.htm>. Acesso em: 22 de maio de 2013

SLACK, N.; CHAMBERS, S.; JOHNSTON, R. Administração da produção. São Paulo: Atlas, 2002.

TACHIZAWA, T. (1997). Organização Flexível. São Paulo, Atlas.

TORESAN, L. (2002). Desempenho e competitividade do setor florestal brasileiro e catarinense.

TUBINO, D. F. Sistema de Produção: A produtividade no chão de fábrica. Porto Alegre. Bookman, 1999.

WEMMERLOV, U; JOHNSON, D.J. Cellular manufacturing at $\mathbf{4 6}$ users plants: implementation experiences andperformance improuvements. International Journal of Production Research, v 35, n 1, pg. 29-49, 1997. crossref

WOMACK, J. P.; JONES, D. T.; ROOS, D. A. A Máquina que mudou o mundo. São Paulo: Campus, 1992.

WOMACK, J.P.; JONES, D.T.A Mentalidade Enxuta nas Empresas, 4 ed. Rio de Janeiro, Editora Campus Ltda,1998.

YIN, Robert K. Estudo de caso - planejamento e métodos. (2Ed.). Porto Alegre: Bookman, 2001. 
ZACKER, D. W.O suprimento enxuto e integrado Análise dos fornecedores de uma empresa brasileira fabricante de motores a diesel. 2004. 123p. Dissertação (Mestrado) - Escolade Engenharia, Universidade Federal do Rio Grande do Sul, Porto Alegre, 2004.

ZOKAEI, K. Application of lean paradigm in red meat processing. British Food Journal, v.107, n.4, p. 192-211. 2005. crossref

Recebido: 05 mar. 2017

Aprovado: 27 out. 2017

DOI: 10.3895/gi.v13n3.5640

Como citar:

LIMA, P. R. B.; MARTINS, V. W. B. Sistema lean para otimização de recursos em uma indústria moveleira: estudo de caso com foco nas ferramentas da produção enxuta. R. Gest. Industr., Ponta Grossa, v. 13, n. 3, p. 112-140, set./nov. 2017. Disponível em: <https://periodicos.utfpr.edu.br/rgi>. Acesso em: XXX. Correspondência:

Patrick Rusivel Brito de Lima

Avenida Hélio da Mota Gueiros, 385, complemento: Bloco H Apt 405; Coqueiro, Belém, Pará, Brasil.

Direito autoral: Este artigo está licenciado sob os termos da Licença Creative Commons-Atribuição 4.0 Internacional.

\section{(c) (1)}

